[Research Paper]

\title{
$\mathrm{ED}-\mathrm{XRF}$ 를 이용한 저온창고의 방화화재 조사기법 연구
}

\author{
김시국 - 채병길 ${ }^{*}$ 한용택 ${ }^{* * \dagger}$ \\ 호서대학교 소방방재학과 교수, ${ }^{*}$ 충청남도 금산소방서 화재조사관, ${ }^{* *}$ 대구한의대학교 소방방재환경전공 교수
}

\section{Investigation Techniques of Arson Fire in Low-Temperature Warehouses Using ED-XRF}

\author{
Si-Kuk Kim $\cdot$ Byeong-Kil Chae ${ }^{*} \cdot$ Yong-Taek $\operatorname{Han}^{* * *}$ \\ Professor, Dept. of Fire and Disaster Protection Engineering, Hoseo Univ., \\ *Fire Investigator, Chungcheongnam-do Geumsan Fire Station, \\ ${ }^{* *}$ Professor, Dept. of Fire and Environmental Safety, Daegu Haany Univ.
}

(Received October 4, 2021; Revised November 9, 2021; Accepted November 12, 2021)

\section{요 약}

본 연구는 ED-XRF를 이용한 저온창고의 방화화재에 대한 조사기법을 연구한 것으로 인화성 액체(휘발유, 시너, 등유, 경유)의 연소열에 의한 시료의 성분 변화를 실험하여 분석한 연구이다. 첫 번째 실험은 시료(아연도금강판+ 우레탄폼+ 샌 드위치패널)를 인화성 액체(휘발유, 시너, 등유, 경유) $500 \mathrm{ml}$ 로 연소시킨 후 시료의 성분 변화를 측정하였다. 연소 실험에서 인화성 액체의 종류에 따라 연소열의 차이는 있었으나, 연소 후 ED-XRF로 시료의 성분 변화를 측정한 결과 휘발유의 연소 실험에서 가장 큰 성분 변화가 측정되었고 시너, 등유, 경유의 순서로 변화가 나타났다. 인화성 액체의 연소열 차이에 의한 시료의 성분 변화를 $\mathrm{ED}-\mathrm{XRF}$ 로 측정함으로써 실험에 사용된 인화성 액체의 구별이 가능하였다. 두 번째 실험은 소방대의 방화화재 진압상황을 가정하여 첫 번째 실험과 동일한 조건에 인화성 액체의 연소 시간을 $600 \mathrm{~s}$ 로 제한하여 실험하였다. 인화성 액체는 종류에 구별없이 공통적으로 연소 시작 후 $300 \mathrm{~s}$ 이내에 온도와 열유속이 최대값에 도달하는 연소 특징이 있어 인화성 액체를 $600 \mathrm{~s}$ 동안 연소 실험한 결과 첫 번째 실험과 동일하게 휘발유, 시너, 등유, 경유 순서로 성분 변화가 확인됨에 따라 방화 현장에서 사용된 인화성 액체를 $\mathrm{ED}-\mathrm{XRF}$ 측정 결과로 구별할 수 있었다. 일반적으로 방화는 연소 과정 에서 대부분의 흔적과 증거물이 소실되고, 화재의 진압 과정에서 현장이 훼손되는 특징이 있어 화재 현장에서 방화의 증거 를 발견하는 것이 어려운 경우가 많기 때문에 ED-XRF를 방화 조사에 활용한다면 방화 현장을 보존한 상태에서 현장을 성 분 분석하여 발화지점의 추정이 가능하고, 방화조사의 신뢰성 향상을 위해서도 적극적인 도입이 필요함을 제안한다.

\section{ABSTRACT}

Investigation techniques for fire prevention in low-temperature warehouses were studied using energy dispersive X-ray fluorescence (ED-XRF). In the first experiment, a sample (galvanized steel sheet plus urethane foam plus sandwich panel) was burned with $500 \mathrm{~mL}$ of a flammable liquid (gasoline, thinner, kerosene, and light oil)/ Then, the component change of the sample was measured. In the combustion experiment, there was a difference in the heat of combustion depending on the type of flammable liquid; however, as a result of measuring the component change of the sample with ED-XRF after combustion, the largest component change was measured in the combustion experiment with gasoline. The change was in the order of thinner, kerosene, and diesel. Using ED-XRF, it was possible to distinguish the flammable liquid used in the experiment by measuring the component change of the sample resulting from the difference in the combustion heat of the flammable liquid. A second experiment was conducted under the same conditions as the first experiment, assuming a fire brigade fire suppression condition, and the combustion time of the flammable liquid was limited to $600 \mathrm{~s}$. A combustion characteristic of flammable liquids is that the temperature and heat flux reach the maximum value within $300 \mathrm{~s}$ after the start of combustion regardless of the type of liquid. Because the change of composition was confirmed in the order of light oil, it was possible to distinguish the flammable liquid used at the fire site using the ED-XRF measurement result.

Keywords : ED-XRF, Flammable liquid, Arson, Low temperature warehouse

\footnotetext{
${ }^{\dagger}$ Corresponding Author, TEL: +82-53-819-1424, FAX: +82-53-819-1273, E-Mail: rthan102@hanmail.net

(c) 2021 Korean Institute of Fire Science \& Engineering. All right reserved.
} 


\section{1. 서 론}

2018년 충청남도 금산군 소재의 저온창고가 ${ }^{(1)}$ 전소된 화 재가 발생하였고 화재조사 과정에서 방화 ${ }^{(2,3)}$ 가 의심되는 요인이 발견되었다. 화재 발생 전 6 개의 화재보험을 가입 한 상태였고, 창고 내에 9 억 5 천만원 상당의 홍미(홍삼뿌 리)가 있었다는 소유자의 주장과는 다르게 Figure 1(a)처럼 창고 내부에서는 홍미의 잔존물이 확인되지 않았다. 또한, 소방서와 $1.2 \mathrm{~km}$ 의 근거리에 위치하고 있음에도 급속한 화 재 진행으로 소방대가 현장 도착 시 저온창고가 전소되어 있었으며, Figure 1(b)와 같이 저온창고의 샌드위치패널 화 재 시 발생된 강한 압력에 의해 지붕이 주변으로 비산된 상태였다. 그리고, Figure 1(c)는 실제 화재가 발생한 구역 의 이해를 돕기 위한 개략도를 보여주고 있다.

또한, 소방·경찰 - 국립과학수사연구원이 ${ }^{(4,5)}$ 합동 조사 를 실시하였으나, 방화 특이점이 식별되지 않았다는 국립 과학수사연구원 감정결과를 토대로 소방은 원인미상의 화 재로 종결 처리했지만, 경찰은 홍미의 거래내역을 수사하 여 소유자와 공범을 검거하였다. 본 화재사례에서 소방과 경찰 모두 방화에 대한 의심을 갖고 있었으나 소방과 경찰 의 화재조사 결과가 상이하게 도출된 원인은 수사권의 유 무에 있다. 현행법상 방화의 경우에는 경찰에게 화재에 대 한 수사권을 인정하고 있어 소방은 방화의 가능성이 있는 화재의 경우 현장 조사까지만 가능하다. 그러나 현장 조사 의 경우도 화재에 대한 합동조사가 실시되면 국립과학수사 연구원이 현장 감식 및 감정을 담당하면서 소방은 국립과 학수사연구원의 감정 결과에 의존한 원인조사를 할 수밖에 없는 실정이다. 이런 현실적 한계의 문제점은 소방과 경찰 의 최근 5 년간 방화통계에서 확인할 수 있다. Figure 2 는 최 근 5년간 소방과 경찰의 방화건수를 나타낸 것으로 소방은 4,618 건, 경찰은 7,155 건으로 동일 화재임에도 불구하고 조 사결과에서 $35.5 \%$ 의 차이가 나타나고 있다. 이러한 차이의 해결을 위해 소방의 방화에 대한 수사권이 필요하나 수사 권의 확보는 법률 개정 등 많은 시간이 소요되므로 현재 소방에게 주어진 현장의 조사 권한 내에서 방화의 요인을 증명해 낼 수 있는 조사기법이 필요하다.

본 논문은 저온창고 화재사례를 바탕으로 비파괴 검사 장비인 energy dispersive X-ray fluorescence (ED-XRF)를 $(6-8)$ 이용하여 방화현장을 보존한 상태에서 화재원인을 조사할 수 있는 기법을 제시하고자, 연소 촉진제로 사용되는 인화 성 액체(휘발유, 시너, 등유, 경유) $)^{(9)}$ 를 시료로 방화현장을 모의하고 ED-XRF를 이용하여 성분함량 변화 등 분석을 진 행하였다 ${ }^{(10-12)}$.

\section{2. 이론적 배경}

\subsection{ED-XRF 작동 원리}

$\mathrm{ED}-\mathrm{XRF}$ 는 X-ray를 이용하여 특정 원자의 다양한 구성

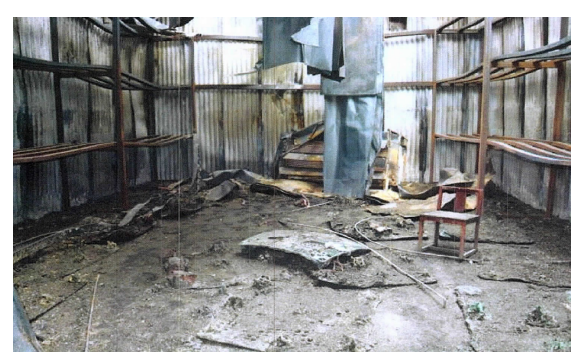

(a) Inside low temperature warehouse

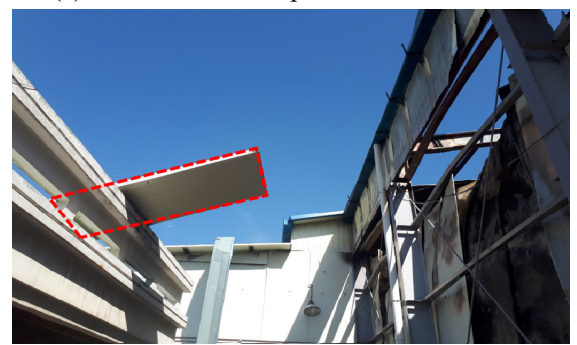

(b) Low temperature warehouse roof

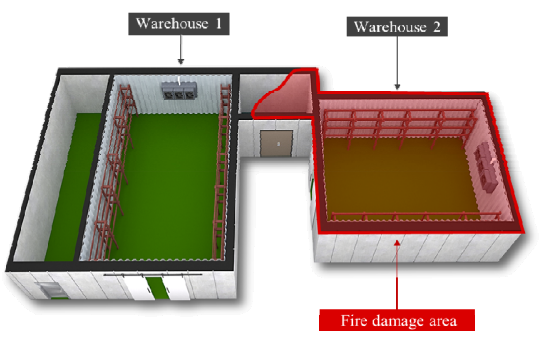

(c) Fire damage area

Figure 1. Low temperature warehouse building layout and combustion shape.

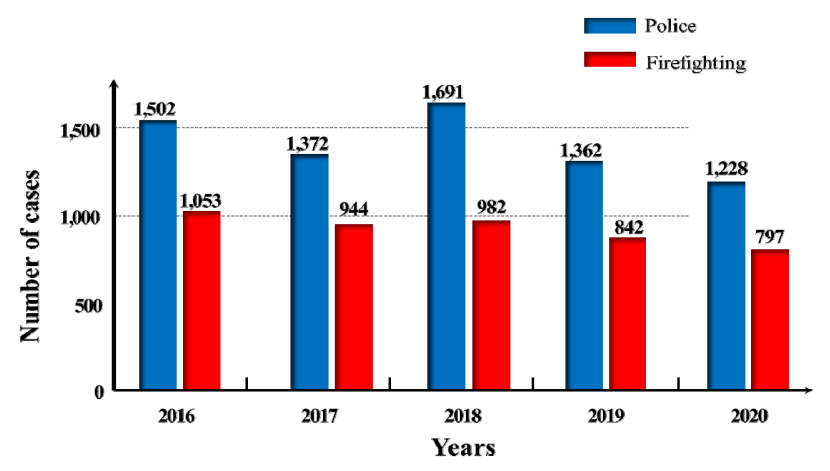

Figure 2. Arson fire statistics for the last 5 years.

요소를 확인할 수 있는 분석 장비이다. X-ray는 에너지가 높고 파장이 짧은 빛으로 물질을 투과하는 성질이 있어 일 반적으로 분석 대상에 조사하면 원자의 핵 부위에 있는 전 자까지 침투하게 된다. Figure 3(a)과 같이 일반적인 상태에 서 X-ray를 조사하면 Figure 3(b)과 같이 핵에 가장 가까운 전자 $(\mathrm{K} \text { shell })^{(13)}$ 가 방출되고, Figure 3(c)과 같이 다른 껍질 $(\mathrm{L} \text { shell })^{(14)}$ 의 전자가 방출된 전자의 자리를 채우면서 전자 고유의 X-ray를 발생시킨다. 이때, 방출된 고유한 특성을 가진 X-ray를 측정하여 원소의 성분을 정성 및 정량 분석 


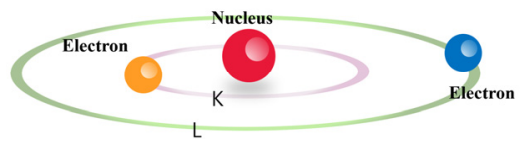

(a) Orbit

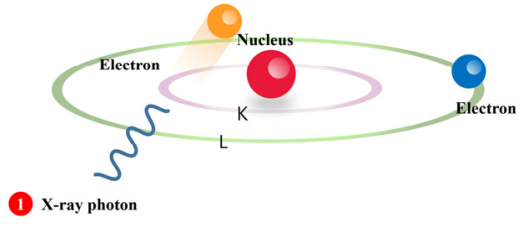

(b) Emit x-rays to electrons

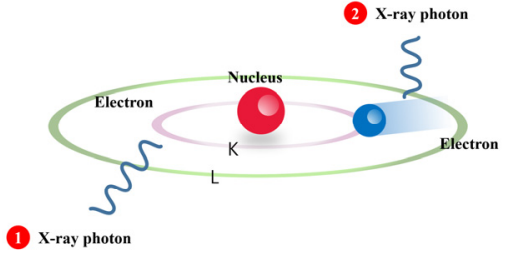

(c) Electrons emit x-rays

Figure 3. X-ray measurement of ED-XRF.

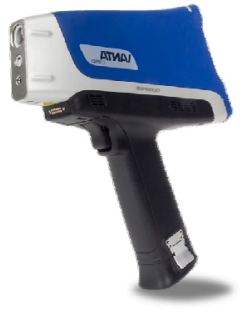

(a) ED-XRF equipment

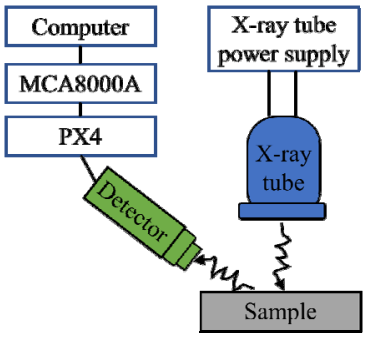

(b) ED-XRF device operation diagram

Figure 4. ED-XRF equipment and operating principles.

하는 장비가 $\mathrm{ED}-\mathrm{XRF}$ 이다.

Figure 4(a)와 같이 ED-XRF는 휴대용 장치로서 과거에 정밀도에 대한 이견이 제시되었으나, 최근까지 정밀도 및 성능향상이 지속적으로 이루어져 다양한 연구 분야에서 사 용되고 있으며, 성분분석을 위해 시편의 제작 등 전처리 과 정 없이 Figure 4(b)와 같이 X선을 시료에 조사한 후 방출 되는 $\mathrm{X}$ 선을 디텍터가 바로 측정을 할 수 있어 시료의 성분 분석이 빠르고, 측정 후 즉시 데이터 처리 및 데이터 베이 스(DB)를 통한 물질의 종류 분석이 가능한 장점을 가지고 있다.

\subsection{ED-XRF 분석}

$\mathrm{ED}-\mathrm{XRF}$ 를 사용한 원리로서는 배열구조 또는 결정구조 를 가진 고체에 X-ray가 조사되면 산란되며, Figure 5 와 같 이 원자들이 일정 간격 $\mathrm{d}$ 로 배열되어 있으면 각 원자로부 터 산란하는 X-ray는 위상 차이에 따라 서로 보강간섭 ${ }^{(15)}$ 또는 상쇄간섭(16)을 한다. 반사된 파의 강도가 최대가 되려 면 보강간섭이 일어날 수 있도록 각 파의 위상이 같아야 하며, 이 법칙은 브래그가 처음으로 발견했다. 식(1)은 브래 그 법칙(bragg's law)을 나타낸 것이다.

$$
n \lambda=2 d \cdot \sin \theta
$$

여기서, $n$ 은 정수, $\lambda$ 는 빛의 파장, $d$ 는 주기 구조의 폭, $\theta$ 는 결정면과 입사된 빛 사이의 각도이다.

$\mathrm{ED}-\mathrm{XRF}$ 는 브래그 법칙을 이용하여 격자상수(d)를 알고 있는 상태에서 파장 $(\lambda)$ 을 측정함으로써 그 원소가 어떤 원 소인지 확인하는 것이다.

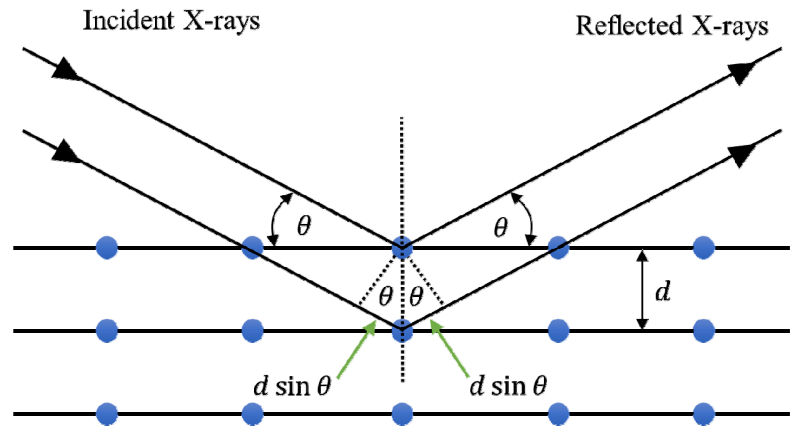

Figure 5. X-ray scattering for crystal structures.

\section{3. 실 험}

\section{1 실험시료}

일반적으로 저온창고는 Figure 6과 같이 외장재인 샌드 위치패널에 내부 단열재로 우레탄폼을 도포하고 마감재로 아연도금강판을 설치하고 있다. 실험시료는 Figure 7 과 같 이 저온창고의 구조와 동일한 '아연도금강판 + 우레탄폼 + 샌드위치패널'을 준비하여 실험하였다. 실험시료의 크기는 가로 $1,000 \mathrm{~mm}$, 세로 $1,000 \mathrm{~mm}$ 의 규격으로 제작하였고, 시 료의 두께는 아연도금강판 $1.2 \mathrm{~mm}$, 샌드위치패널 $150 \mathrm{~mm}$ 의 제품을 사용하였고, 우레탄폼은 $30 \mathrm{~mm}$ 로 도포하였다. 또한, 방화화재에서 연소 촉진제로 많이 사용되는 인화성 액체 중 휘발유, 시너, 등유, 경유를 이용하여 연소실험을 실시하였다.

\section{2 실험방법}

Figure 8 과 같이 연소실을 가로 $1,500 \mathrm{~mm}$, 세로 $1,500 \mathrm{~mm}$ 


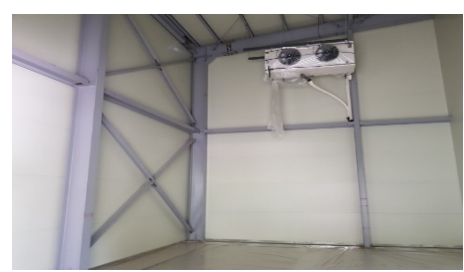

(a) Sandwich panel

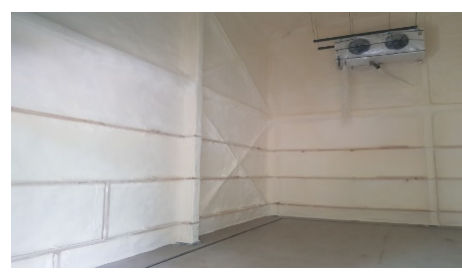

(b) Urethane foam

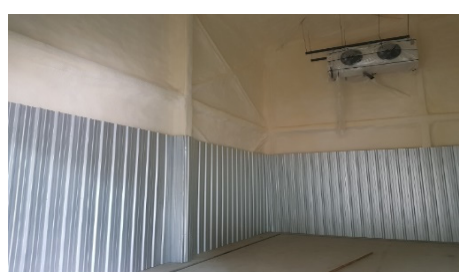

(c) Galvanized steel

Figure 6. Insulation construction process of low-temperature warehouse.

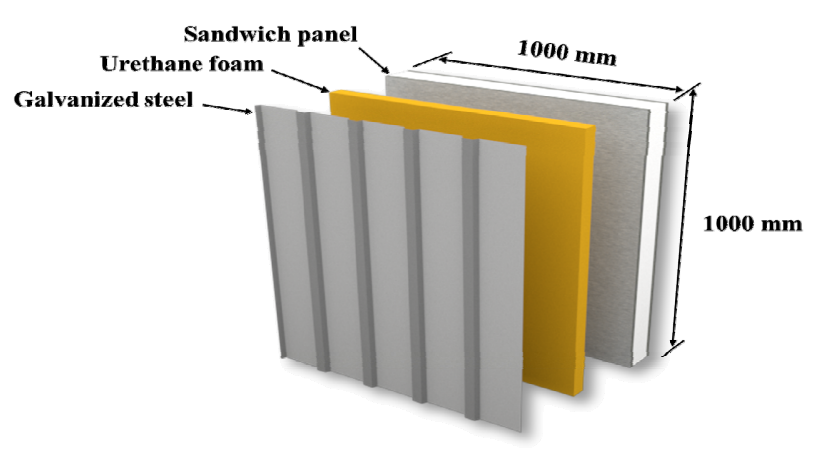

Figure 7. Experimental specimens.

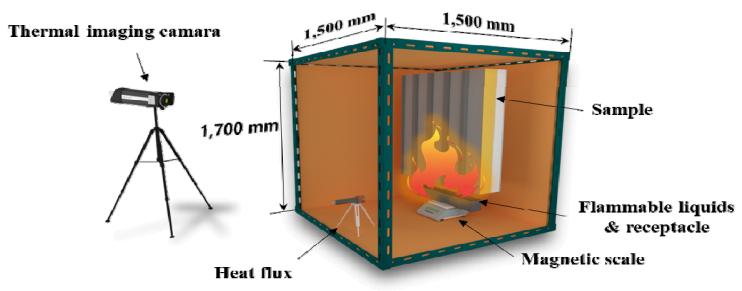

(a) Combustion chamber

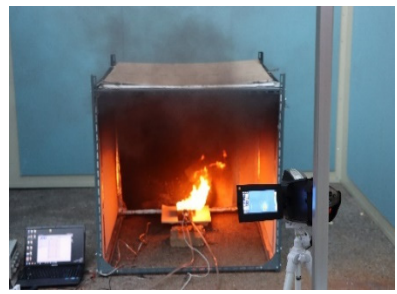

(b) Photograph

Figure 8. Combustion chamber and measuring equipment.

및 높이 $1,700 \mathrm{~mm}$ 크기로 제작하였고, 벽면에 불연재를 설 치하고 전면만 개방한 상태에서 연소 실험을 실시하였다. 실험시료를 연소실 내부에 설치하고 시료의 하부에서 인화 성 액체를 연소시키는 방식으로 실험하고, 연소 실험에 의한 온도변화를 열화상카메라(Testo 890, Testo Co., Germany)로 측정하였다. 또한, 인화성 액체를 담은 연소 용기의 하부에 연소 시 질량감소율 측정을 위한 전자저울(EK-6100i, A\&D Company Limited., Japan)과 연소 시 발생되는 복사열량을 측정하기 위하여 화염으로부터 약 $50 \mathrm{~cm}$ 거리를 두어서 측 정부위의 하단에 열유속계를 설치하고, 데이터로거(GP20,

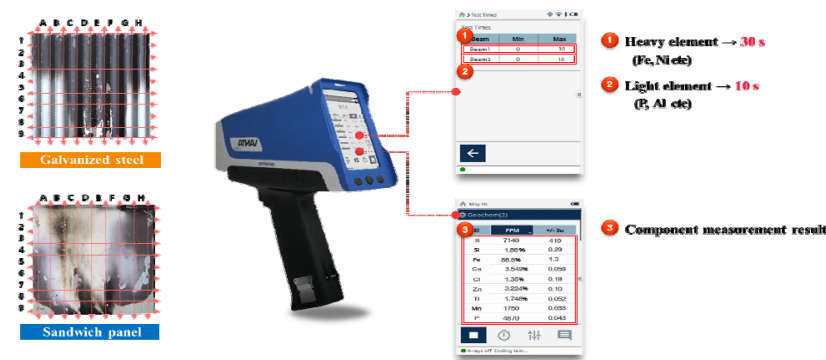

Figure 9. Sample measurement with ED-XRF.

YOKOGAWA Electric Corporation., Japan)를 이용하여 실험 시 인화성 액체의 연소량과 열유속계의 데이터를 결합하여 연소 과정에서 발생한 바닥면의 열유속 값 $\left(\mathrm{kW} / \mathrm{m}^{2}\right)$ 을 산출하 였다. 실험시료에 대한 인화성 액체별 연소 실험은 Figure 8(a)와 Figure 8(b)로 나누어 각각 3회씩 실시하여 평균값을 이용하여 분석하였으며, 10 회 이상의 예비실험을 통한 신뢰 성을 확보하였으며, 반복 실험 시 유의미한 편차는 보이지 않았다.

Figure 8(a)는 시료를 인화성 액체 $500 \mathrm{ml}$ 로 전소시킨 후 인화성 액체의 연소열에 의한 시료의 성분 변화를 $\mathrm{ED}-\mathrm{XRF}$ 로 측정하고, 실험 중 확인된 시료의 최대 온도 및 열유속 값 과의 연관성을 분석하였다. Figure $8(\mathrm{~b})$ 는 방화 현장에 소방 대가 도착하여 화재를 진압한 상황을 가정하여 시료를 인화 성 액체로 $600 \mathrm{~s}$ 동안 연소시킨 후 $\mathrm{ED}-\mathrm{XRF}$ 로 시료의 성분 변화를 측정하여 Figure $8(\mathrm{a})$ 의 결과 값과 비교 분석으로 연 소 시간에 의한 성분 차이를 확인하고자 하였다.

$\mathrm{ED}-\mathrm{XRF}$ 분석은 Figure 9와 같이 연소 실험 후 시료의 표면 을 측정하는 방법을 사용하였다. 측정 시간은 Figure 9처럼 무 거운 원소 $(\mathrm{Fe}, \mathrm{Ni}$ 등)는 $30 \mathrm{~s}$, 가벼운 원소 $(\mathrm{P}, \mathrm{Al}$ 등)는 $10 \mathrm{~s}$ 로 설정하였고, Figure 9와 같이 측정된 데이터 결과를 통 해 시료의 성분분석을 하였다.

\section{4. 실험결과 및 분석}

\subsection{Case 1 결과}

Figure 10은 실험시료(아연도금강판 + 우레탄폼 + 샌드위 치패널)를 인화성 액체(휘발유, 시너, 등유, 경유) $500 \mathrm{ml}$ 로 각각 연소시켰을 때, 시료의 온도변화와 열유속 값을 나타 낸 것이다. Figure $10(\mathrm{a})$ 은 휘발유의 실험결과로 $680 \mathrm{~s}$ 간 연 


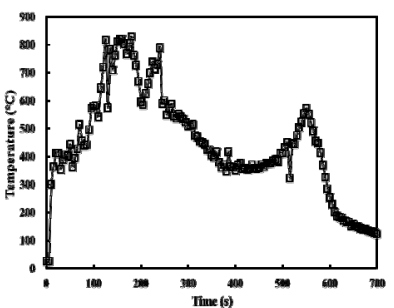

(a-1) Temperature

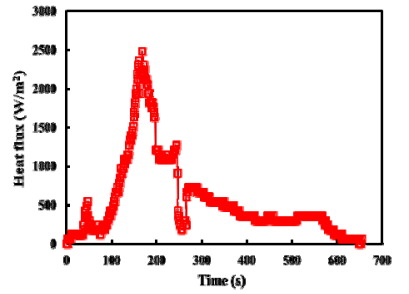

(a-2) Heat flux

(a) Gasoline

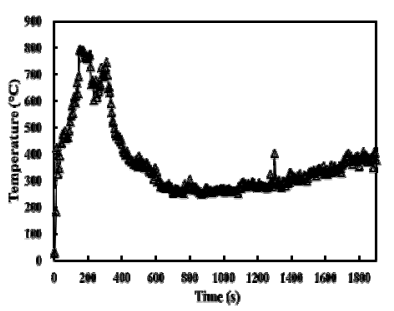

(c-1) Temperature

(c) Kerosene

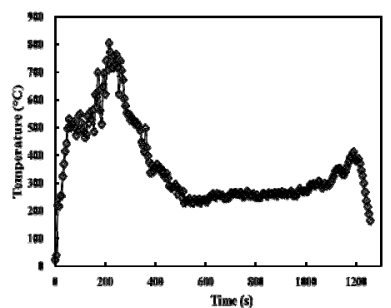

(b-1) Temperature

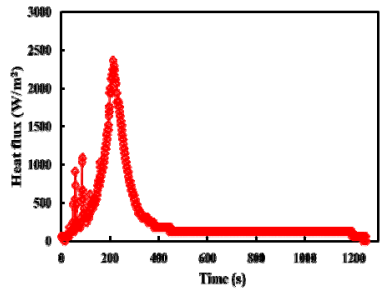

(b-2) Heat flux

(b) Thinner

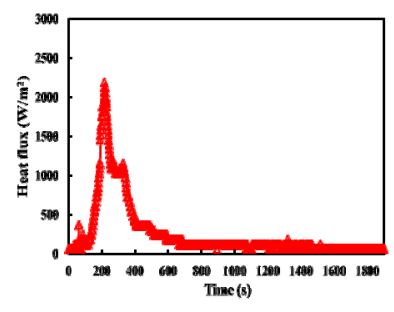

(c-2) Heat flux

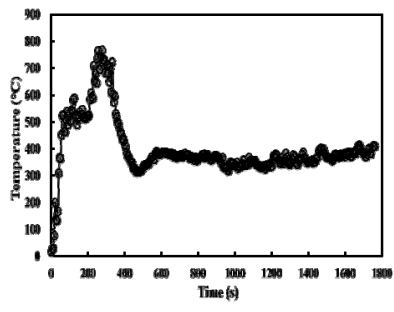

(d-1) Temperature

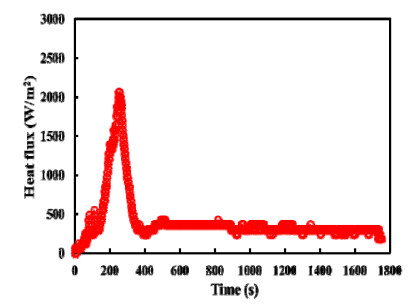

(d-2) Heat flux

(d) Diesel

Figure 10. Specimen combustion experiment (complete combustion of flammable liquids).

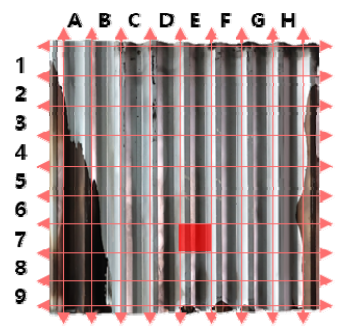

(a) Gasoline

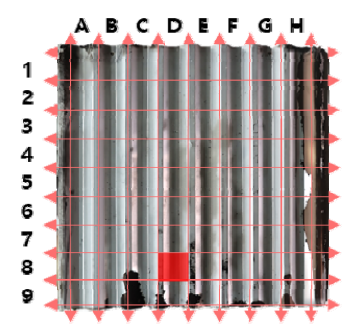

(b) Thinner

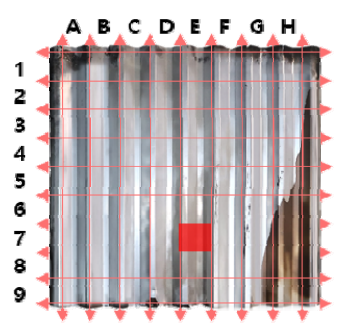

(c) Kerosene

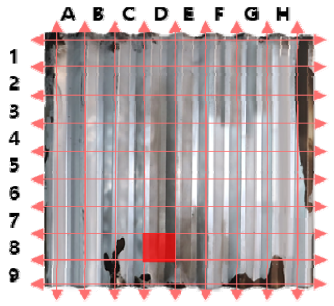

(d) Diesel

Figure 11. Galvanized steel pattern on complete combustion.

소가 진행되었고, 최대 $814.2{ }^{\circ} \mathrm{C}$ 까지 온도가 상승하는 것으 로 측정되었다. 이때, 열유속 값은 평균 $0.4 \mathrm{~kW} / \mathrm{m}^{2}$, 최대 $2.5 \mathrm{~kW} / \mathrm{m}^{2}$ 로 나타났다. Figure 10(b)은 시너의 실험결과로 $1,255 \mathrm{~s}$ 간 연소가 진행되었고, 최대 $805.3{ }^{\circ} \mathrm{C}$ 까지 온도가 상승하는 것으로 측정되었다. 이때, 열유속 값은 평균 0.3 $\mathrm{kW} / \mathrm{m}^{2}$, 최대 $2.3 \mathrm{~kW} / \mathrm{m}^{2}$ 로 나타났다. Figure 10 (c)은 등유의 실험결과로 $1,915 \mathrm{~s}$ 간 연소가 진행되었고, 최대 $792.7{ }^{\circ} \mathrm{C}$ 까 지 온도가 상승하는 것으로 측정되었다. 이때, 열유속 값은 평균 $0.2 \mathrm{~kW} / \mathrm{m}^{2}$, 최대 $2.1 \mathrm{~kW} / \mathrm{m}^{2}$ 로 나타났다. Figure $10(\mathrm{~d})$ 은 경유의 실험결과로 $1,794 \mathrm{~s}$ 간 연소가 진행되었고, 최대 $765.7{ }^{\circ} \mathrm{C}$ 까지 온도가 상승하는 것으로 측정되었다. 이때, 열유속 값은 평균 $0.4 \mathrm{~kW} / \mathrm{m}^{2}$, 최대 $2.0 \mathrm{~kW} / \mathrm{m}^{2}$ 로 나타났다.

인화성 액체의 연소 실험결과 $500 \mathrm{ml}$ 를 전소시키는 과정 에서 액체별 연소 시간의 차이를 관찰할 수 있었고, 온도와 열유속의 최대 값도 다르게 나타났다. 인화성 액체의 연소 열에 의한 온도와 열유속의 값은 휘발유가 가장 높게 측정 되었고, 다음으로 시너, 등유, 경유 순으로 결과값이 확인 되었다. 인화성 액체는 종류에 따라 차이는 있으나 공통적
으로 연소 실험 $300 \mathrm{~s}$ 이내에 온도와 열유속이 최대값에 도 달하는 연소특성을 보였고, 인화성 액체의 연소 과정에서 시료의 최대 온도가 측정된 시간대와 열유속의 최대값이 측정된 시간대가 일치하는 결과가 나타났다.

Figure 11의 아연도금강판과 Figure 12의 샌드위치패널강 판을 가로 8 등분 $(\mathrm{A} \sim \mathrm{H})$, 세로 9 등분(1 9)으로 분할하고, 시료의 하부에서 인화성 액체를 연소시키는 과정에서 수열 받은 시료의 성분 변화를 측정하였다. 아연도금강판의 성 분 변화를 측정한 결과 Figure 11과 같이 휘발유는 E-7, 시 너는 D-8, 등유는 E-7, 경유는 D-8 지점에서 최대값이 확인 되었다. 샌드위치패널강판의 성분 변화는 Figure 12 와 같이 휘발유는 F-8, 시너는 E-8, 등유는 F-8, 경유는 F-7 지점에 서 최대값이 확인되었다. Tables 1 과 2 는 아연도금강판과 샌드위치패널강판의 최대 성분 변화지점을 $\mathrm{ED}-\mathrm{XRF}$ 로 측 정한 결과값을 나타낸 것이다. Table 1에서 아연도금강판의 $\mathrm{Fe}$ 원소 비율은 실험 전 $83.2 \%$ 에서 인화성 액체의 연소 실 험결과 휘발유는 $91.3 \%$, 시너는 $90.5 \%$, 등유는 $87.1 \%$, 경유 는 $86.9 \%$ 로 증가하였고, Table 2 에서 샌드위치패널강판의 


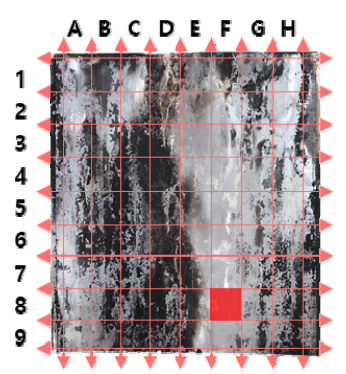

(a) Gasoline

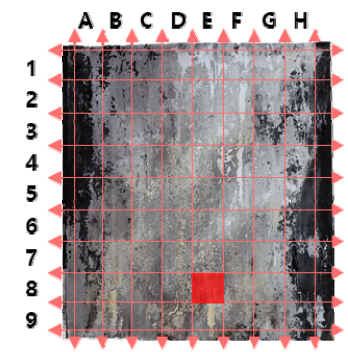

(b) Thinner

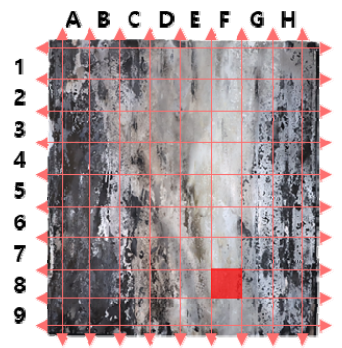

(c) Kerosene

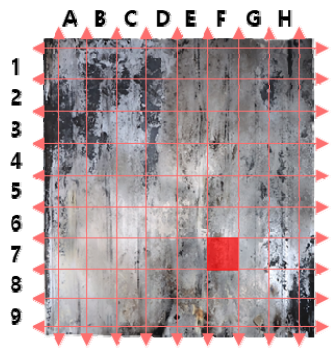

(d) Diesel

Figure 12. Sandwich panel pattern on complete combustion.

Table 1. Maximum Point Analyzed by ED-XRF for Complete Combustion (Galvanized Steel)

\begin{tabular}{c|c|c|c|c|c|c}
\hline Components & \multicolumn{5}{|c|}{ Galvanized steel } & \multirow{2}{*}{+ Diesel } \\
\hline Element & General component & Gasoline & Thinner & Kerosene & \multicolumn{2}{c}{ D } \\
\hline \hline $\mathrm{Fe}$ & $83.20 \%$ & $91.30 \%$ & $89.80 \%$ & $87.90 \%$ & $86.90 \%$ & 1.3 \\
\hline $\mathrm{S}$ & $0.63 \%$ & $0.56 \%$ & $0.71 \%$ & $0.73 \%$ & $0.99 \%$ & 410 \\
\hline $\mathrm{Ca}$ & $3.57 \%$ & - & - & - & $0.23 \%$ & 0.059 \\
\hline $\mathrm{Ti}$ & $1.79 \%$ & - & $0.14 \%$ & $0.19 \%$ & $1.70 \%$ & 0.052 \\
\hline $\mathrm{Zn}$ & $6.63 \%$ & $5.11 \%$ & $5.49 \%$ & $7.10 \%$ & $4.72 \%$ & 0.10 \\
\hline $\mathrm{Si}$ & $1.87 \%$ & $1.79 \%$ & $2.71 \%$ & $2.78 \%$ & $3.25 \%$ & 0.29 \\
\hline $\mathrm{etc}$ & $2.31 \%$ & $1.24 \%$ & $1.15 \%$ & $1.30 \%$ & $2.21 \%$ & 0.14 \\
\hline
\end{tabular}

Table 2. Maximum Point Analyzed by ED-XRF for Complete Combustion (Sandwich Panel)

\begin{tabular}{|c|c|c|c|c|c|c|}
\hline Components & \multicolumn{5}{|c|}{ Galvanized steel } & \multirow{2}{*}{$+/-2 \sigma$} \\
\hline El & General component & Gasoline & Thinner & Kerosene & Diesel & \\
\hline $\mathrm{Fe}$ & $70.5 \%$ & $91.70 \%$ & $90.50 \%$ & $87.10 \%$ & $86.20 \%$ & 1.3 \\
\hline $\mathrm{S}$ & $2.98 \%$ & $0.71 \%$ & $1.15 \%$ & $1.17 \%$ & $1.19 \%$ & 410 \\
\hline $\mathrm{Ca}$ & $0.87 \%$ & - & $0.06 \%$ & $0.31 \%$ & $0.31 \%$ & 0.059 \\
\hline $\mathrm{Ti}$ & $8.98 \%$ & $0.1 \%$ & $0.57 \%$ & $0.75 \%$ & $1.30 \%$ & 0.052 \\
\hline $\mathrm{Zn}$ & $6.59 \%$ & $4.41 \%$ & $4.09 \%$ & $4.54 \%$ & $4.68 \%$ & 0.10 \\
\hline $\mathrm{Si}$ & $7.64 \%$ & $1.93 \%$ & $1.90 \%$ & $3.8 \%$ & $2.76 \%$ & 0.29 \\
\hline etc & $2.44 \%$ & $1.15 \%$ & $1.73 \%$ & $2.33 \%$ & $3.56 \%$ & 0.14 \\
\hline
\end{tabular}

$\mathrm{Fe}$ 원소 비율은 실험 전 $70.5 \%$ 에서 휘발유는 $91.7 \%$, 시너 는 $90.5 \%$, 등유는 $87.1 \%$, 경유는 $86.2 \%$ 로 증가하였다. 아연 도금강판과 샌드위치패널강판은 내식성을 높이기 위해 강 철에 아연 도금을 한 제품으로 아연도금강판과 샌드위치패 널강판은 성분 비율의 차이가 있으나 $\mathrm{Fe}$ 의 아연 도금 과정 에서 $\mathrm{Zn}, \mathrm{S}, \mathrm{Ca}, \mathrm{Ti}, \mathrm{Si}$ 등의 원소가 공통적으로 사용된다.

Tables 1과 2에서 $\mathrm{Fe}$ 원소가 증가하는 결과값이 나타난 원인은 인화성 액체의 연소열에 수열 받은 아연도금강판과 샌드위치패널강판의 $\mathrm{Zn}, \mathrm{S}, \mathrm{Ca}, \mathrm{Ti}, \mathrm{Si}$ 등의 원소가 용융되 면서 성분비가 감소하자 상대적으로 용융되지 않은 $\mathrm{Fe}$ 원 소의 성분 비율이 상승한 것으로 사료된다. 또한, 인화성 액체의 연소열에 의한 시료의 성분 변화를 측정하는 실험 을 통해 인화성 액체의 종류에 따라 온도와 열유속의 최대
값에 차이가 있고, 인화성 액체의 연소 시간보다 연소열의 최대 온도 및 열유속 값이 시료의 성분을 변화시키는 요인 으로 분석됨에 따라 인화성 액체의 연소 과정에서 수열 받 은 시료의 성분 변화를 $\mathrm{ED}-\mathrm{XRF}$ 로 측정한 결과값으로 방화 현장에서 사용된 인화성 액체의 구분이 가능할 수 있을 것 이라 판단된다.

\subsection{Case 2 결과}

Figure 13은 방화 현장에 소방대가 도착하여 화재를 진 압한 상황을 가정하여 시료(아연도금강판 + 우레탄폼 + 샌 드위치패널)를 인화성 액체(휘발유, 시너, 등유, 경유)로 $600 \mathrm{~s}$ 동안 연소시킨 후 시료의 온도변화와 열유속 값을 나 타낸 것이다. Figure 13(a)은 휘발유의 실험결과로 최대 


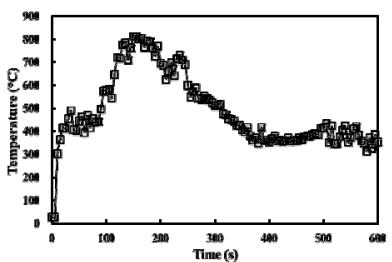

(a-1) Temperature

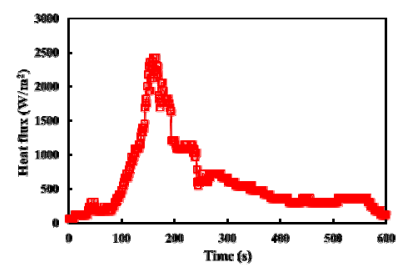

(a-2) Heat flux

(a) Gasoline
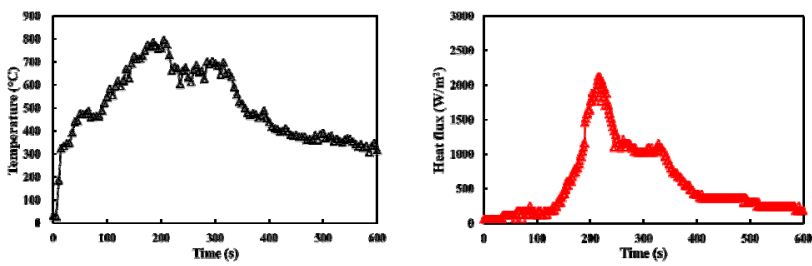

(c-1) Temperature

(c) Kerosene

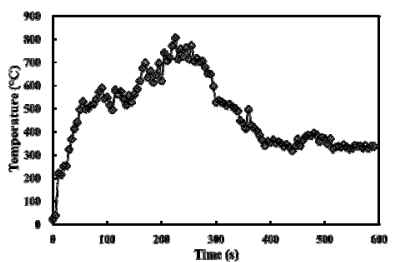

(b-1) Temperature

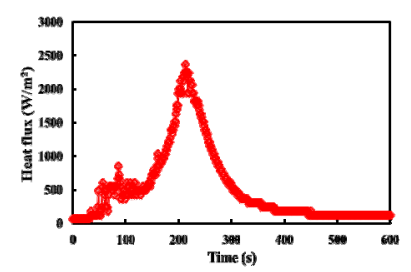

(b-2) Heat flux

(b) Thinner

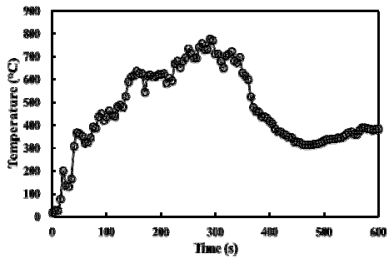

(d-1) Temperature

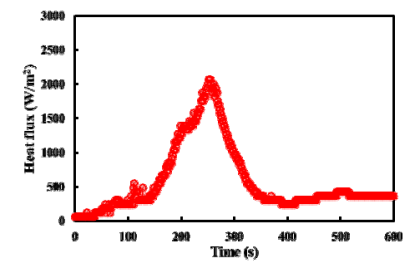

(d-2) Heat flux

(d) Diesel

Figure 13. Specimen combustion experiment (600 s combustion of flammable liquids).

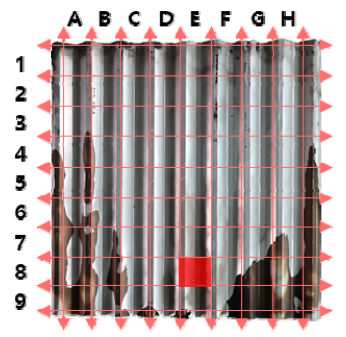

(a) Gasoline

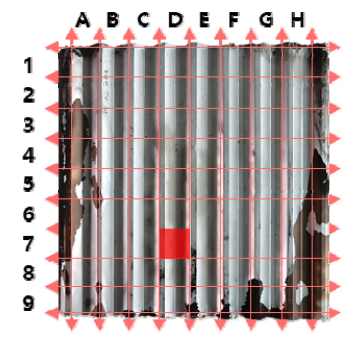

(b) Thinner

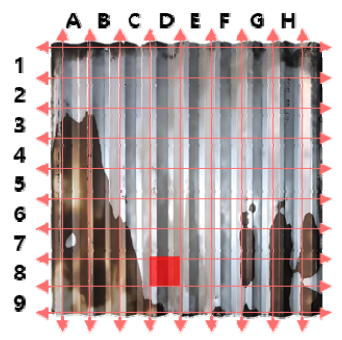

(c) Kerosene

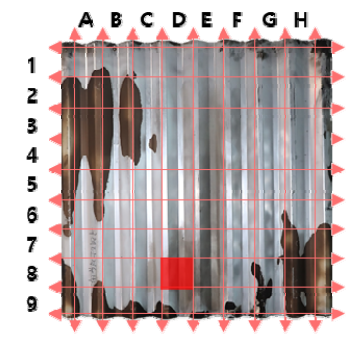

(d) Diesel

Figure 14. Galvanized steel pattern on $600 \mathrm{~s}$ combustion.

$811.5{ }^{\circ} \mathrm{C}$ 까지 온도가 상승하였고, 열유속 값은 평균 1.1 $\mathrm{kW} / \mathrm{m}^{2}$, 최대 $2.7 \mathrm{~kW} / \mathrm{m}^{2}$ 로 나타났다. Figure 13(b)은 시너의 실험결과로 최대 $806.2{ }^{\circ} \mathrm{C}$ 까지 온도가 상승하였고, 열유속 값은 평균 $1.2 \mathrm{~kW} / \mathrm{m}^{2}$, 최대 $2.6 \mathrm{~kW} / \mathrm{m}^{2}$ 로 나타났다. Figure $13(\mathrm{c})$ 은 등유의 실험결과로 최대 $795.4{ }^{\circ} \mathrm{C}$ 까지 온도가 상승하였 고, 열유속 값은 평균 $0.5 \mathrm{~kW} / \mathrm{m}^{2}$, 최대 $2.1 \mathrm{~kW} / \mathrm{m}^{2}$ 로 나타났 다. Figure $13(\mathrm{~d})$ 은 경유의 실험결과로 최대 $776.1{ }^{\circ} \mathrm{C}$ 까지 온 도가 상승하였고, 열유속 값은 평균 $0.5 \mathrm{~kW} / \mathrm{m}^{2}$, 최대 2.0 $\mathrm{kW} / \mathrm{m}^{2}$ 로 나타났다.

인화성 액체의 $600 \mathrm{~s}$ 연소 실험에서 온도와 열유속의 최 대값은 Case 1의 Figure 10에서 확인된 결과값과 유의미한 차이는 확인되지 않았다. 이와 같은 결과는 인화성 액체가 종류에 구분 없이 연소 실험 $300 \mathrm{~s}$ 이내에 온도와 열유속이 최대값에 도달하는 연소 특징이 있어, $600 \mathrm{~s}$ 의 연소 실험에 서 휘발유, 시너, 등유, 경유 순서로 측정된 온도와 열유속 의 최대값은 Case 1 의 결과값과 차이가 없었던 것으로 분 석되었다.

아연도금강판과 샌드위치패널강판을 Figures 14 와 15 처 럼 8등분(A $\sim \mathrm{H})$, 세로 9등분(1 9)으로 분할하고 인화성 액 체의 연소열에 의한 성분 변화를 $\mathrm{ED}-\mathrm{XRF}$ 로 측정하였다.
Figure 14는 아연도금강판을 측정하여 성분 변화의 최대값 이 나타난 지점을 적색으로 표시한 것으로 휘발유는 E-8, 시너는 D-7, 등유는 D-8, 경유는 D-8 지점에서 최대값이 확 인되었다. Figure 15 에서 샌드위치패널강판의 최대값은 휘 발유는 D-7, 시너는 F-7, 등유는 D-8, 경유는 F-7 지점에서 확인되었다. Tables 3 과 4는 Figurs 14 와 15 에서 확인된 성 분 변화의 최대값 지점을 $\mathrm{ED}-\mathrm{XRF}$ 로 측정한 결과값으로 $\mathrm{Si}$, $\mathrm{S} . \mathrm{Ca}, \mathrm{Ti}, \mathrm{Zn}$ 원소가 용융되면서 아연도금강판에서 $\mathrm{Fe}$ 원 소의 비율은 실험 전 $83.2 \%$ 에서 휘발유가 $90.7 \%$, 시너는 $88.9 \%$, 등유는 $87.9 \%$, 경유는 $87.0 \%$ 로 확인되었고, 샌드위 치패널강판에서 $\mathrm{Fe}$ 원소의 비율은 실험 전 $70.5 \%$ 에서 휘 발유가 $89.9 \%$, 시너는 $88.9 \%$, 등유는 $86.6 \%$, 경 유는 $86.0 \%$ 로 확인되었다. 아연도금강판과 샌드위치패널강판을 $10 \mathrm{~min}$ 간 연소하는 실험에서 $\mathrm{Fe}$ 원소의 성분비는 실험 1 과 비교 해 인화성 액체의 종류별 최대값이 다소 낮게 확인되었으 나 성분 변화의 값은 휘발유, 시너, 등유, 경유의 순서로 나 타나 ED-XRF의 측정값으로 인화성 액체의 종류 구별의 가 능할 수 있을 것으로 사료되는 결과를 얻을 수 있었다. 그 러나, 향후 방화문, 출입문등 다양한 시료 조건에서의 인화 성액체의 종류에 따른 시료의 성분 분석을 통한 방화시의 
Table 3. Maximum Point Analyzed by ED-XRF at 10-minute Combustion (Galvanized Steel)

\begin{tabular}{c|c|c|c|c|c|c}
\hline Components & \multicolumn{5}{|c|}{ Galvanized steel } & \multirow{2}{*}{+ Diesel } \\
\hline $\mathrm{El}$ & General component & Gasoline & Thinner & Kerosene & \multicolumn{2}{c}{$2 \sigma$} \\
\hline \hline $\mathrm{Fe}$ & $83.20 \%$ & $90.70 \%$ & $88.90 \%$ & $87.90 \%$ & $87.00 \%$ & 1.3 \\
\hline $\mathrm{S}$ & $0.63 \%$ & $0.56 \%$ & $0.71 \%$ & $0.73 \%$ & $0.99 \%$ & 410 \\
\hline $\mathrm{Ca}$ & $3.57 \%$ & - & - & - & $0.23 \%$ & 0.059 \\
\hline $\mathrm{Ti}$ & $1.79 \%$ & - & $0.14 \%$ & $0.19 \%$ & $0.20 \%$ & 0.052 \\
\hline $\mathrm{Zn}$ & $6.63 \%$ & $5.41 \%$ & $5.89 \%$ & $7.26 \%$ & $7.72 \%$ & 0.10 \\
\hline $\mathrm{Si}$ & $1.87 \%$ & $1.89 \%$ & $2.83 \%$ & $3.02 \%$ & $3.40 \%$ & 0.29 \\
\hline $\mathrm{etc}$ & $2.31 \%$ & $1.44 \%$ & $1.53 \%$ & $0.9 \%$ & $0.46 \%$ & 0.14 \\
\hline
\end{tabular}

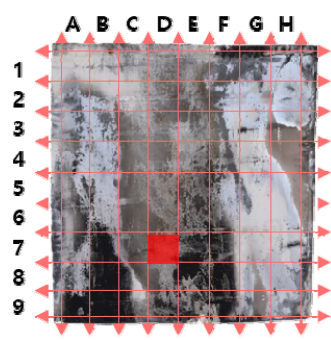

(a) Gasoline

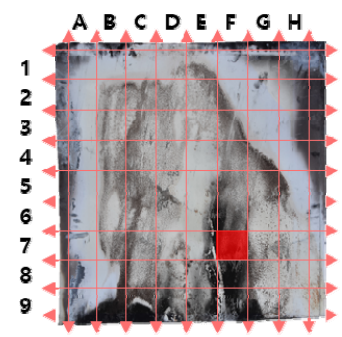

(b) Thinner

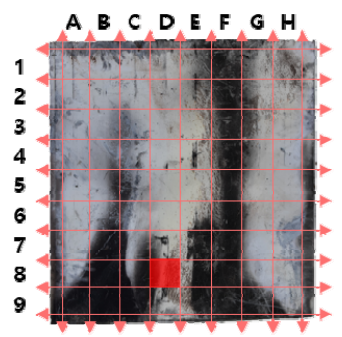

(c) Kerosene

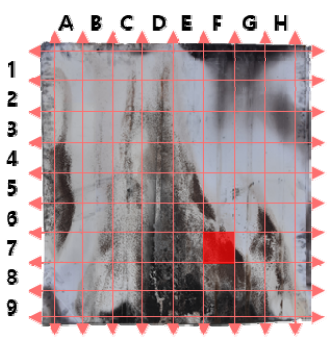

(d) Diesel

Figure 15. Sandwich panel pattern on $600 \mathrm{~s}$ combustion.

Table 4. Maximum Point Analyzed by ED-XRF at 10-minute Combustion (Sandwich Panel)

\begin{tabular}{|c|c|c|c|c|c|c|}
\hline \multirow{2}{*}{$\begin{array}{c}\text { Components } \\
\text { El }\end{array}$} & \multicolumn{5}{|c|}{ Galvanized Steel } & \multirow{2}{*}{$+/-2 \sigma$} \\
\hline & General component & Gasoline & Thinner & Kerosene & Diesel & \\
\hline $\mathrm{Fe}$ & $70.50 \%$ & $89.90 \%$ & $88.90 \%$ & $86.60 \%$ & $86.00 \%$ & 1.3 \\
\hline $\mathrm{S}$ & $2.98 \%$ & $1.01 \%$ & $1.31 \%$ & $1.55 \%$ & $1.69 \%$ & 410 \\
\hline $\mathrm{Ca}$ & $0.87 \%$ & - & $0.06 \%$ & $0.31 \%$ & $0.31 \%$ & 0.059 \\
\hline $\mathrm{Ti}$ & $8.98 \%$ & $0.34 \%$ & $0.58 \%$ & $0.62 \%$ & $1.15 \%$ & 0.052 \\
\hline $\mathrm{Zn}$ & $6.59 \%$ & $4.41 \%$ & $4.89 \%$ & $5.76 \%$ & $5.89 \%$ & 0.10 \\
\hline $\mathrm{Si}$ & $7.64 \%$ & $1.81 \%$ & $2.11 \%$ & $3.33 \%$ & $3.62 \%$ & 0.29 \\
\hline etc & $2.44 \%$ & $2.53 \%$ & $2.15 \%$ & $1.83 \%$ & $1.34 \%$ & 0.14 \\
\hline
\end{tabular}

인화성액체 종류에 대한 판별 가능성에 대한 추가 연구는 필요한 실험조건이다.

\section{5. 결 론}

본 연구는 $\mathrm{ED}-\mathrm{XRF}$ 를 이용한 저온창고의 방화화재에 대 한 조사기법을 연구한 것으로 인화성 액체(휘발유, 시너, 등유, 경유)의 연소열에 의한 시료의 성분 변화를 실험하여 다음과 같은 결론을 도출하였다.

1) Case 1은 시료(아연도금강판 + 우레탄폼 + 샌드위치 패널)를 인화성 액체(휘발유, 시너, 등유, 경유) $500 \mathrm{ml}$ 로 연 소시킨 후 시료의 성분 변화를 측정했다. 연소 실험에서 인 화성 액체의 종류에 따라 연소열의 차이는 있었으나, 연소
후 $\mathrm{ED}-\mathrm{XRF}$ 로 시료의 성분 변화를 측정한 결과 휘발유의 연소 실험에서 가장 큰 성분 변화가 측정되었고, 시너, 등 유, 경유의 순서로 변화가 나타났다. 인화성 액체의 연소열 차이에 의한 시료의 성분 변화를 $\mathrm{ED}-\mathrm{XRF}$ 로 측정함으로써 실험에 사용된 인화성 액체의 구별이 가능하였다.

2) Case 2는 소방대의 방화화재 진압상황을 가정하여 실 험 1 과 동일한 조건에 인화성 액체의 연소 시간을 $600 \mathrm{~s}$ 로 제한하여 실험하였다. 인화성 액체는 종류에 구별 없이 공통 적으로 연소 시작 후 $300 \mathrm{~s}$ 이내에 온도와 열유속이 최대값 에 도달하는 연소 특징이 있어 인화성 액체를 $600 \mathrm{~s}$ 동안 연 소 실험한 결과 실험 1 과 동일하게 휘발유, 시너, 등유, 경유 순서로 성분 변화가 확인됨에 따라 방화 현장에서 사용된 인화성 액체를 $\mathrm{ED}-\mathrm{XRF}$ 측정 결과로 구별할 수 있었다. 
3) 방화는 연소 과정에서 대부분의 흔적과 증거물이 소 실되고, 화재의 진압 과정에서 현장이 훼손되는 특징이 있 어 화재 현장에서 방화의 증거를 발견하는 것이 어려운 경 우가 많다. ED-XRF를 방화 조사에 활용한다면 방화현장을 보존한 상태에서 현장을 성분 분석하여 발화지점의 추정이 가능하고, 나아가 방화를 증명할 수 있는 자료를 제공해 줄 수 있다는 점에서 화재조사 분야에 적극적인 도입이 필요 할 것으로 생각된다.

\section{References}

1. B. I. Yu, "A Study on the Risk of Fire Magnetic Contactor at the Control Panel of Refrigeration Warehouse", Korean Society of Disaster Information, Vol. 15, No. 3, pp. 313-322 (2019). https://doi.org/10.15683/kosdi.2019.09.30.313.

2. M. K. Choi, D. H. Han and D. M. Choi, "Arson Fire Analysis Involving the Use of Flammable Liquids as Accelerants", Fire Science and Engineering, Vol. 28, No. 4, pp. 64-72 (2014). https://doi.org/10.7731/KIFSE.2014.28.4.064.

3. K. B. Ko, S. Y. Lee and J. Choi, "A Study on Fire-fighter and Police Officer's Perception about the Arson Cause Investigation", Fire Science and Engineering, Vol. 24, No. 3, pp. 25-32 (2010).

4. B. I. Jo, "A Study on the Forensic Science Research and Scientific Investigation in Korea", Korean Institute of Criminology and Justice, Vol. 20, No. 1, pp. 1911-1228 (2009).

5. J. K. Chung, Y. J. Cho, M. H. Lee, D. S. Lee and J. M. Lee, "Current Management Status of Elimination DNA Database in NFS and Plans for Improvement of Analysis Quality", Applied Science and Convergence Technology, Vol. 21, No. 1, pp. 14-19 (2021).

6. S. J. Yu and K. L. Chung, "A Study on the Application of Metal-Based Forensic Evidence Using the Portable X-ray Fluorescence Spectrometer(PXRF)", Policejournal, Vol. 18, No. 3, pp. 193-206 (2018). https://doi.org/10.22816/polsci.2018. 18.3.008.

7. J. H. Sim and N. W. Cho, "Fire Performance Testing Method for Fire Retardant EPS Sandwich Panel Using X-ray Analysis", Fire Science and Engineering, Vol. 29, No. 6, pp. 76-83 (2015). https://doi.org/10.7731/KIFSE.2015.29.6.076.

8. S. S. Kim, Y. S. Lee, D. Y. Kim and D. S. Ko, "Study for Enhancement of the Detection Sensitivity in hand-held
Fluorescence Device", Applied Science and Convergence Technology, Vol. 20, No. 6, pp. 409-415 (2011). https://doi. org/10.5757/JKVS.2011.20.6.409

9. H. S. Cho and C. S. Choi, "Analysis of Fire Patterns of Flammble Liquids for Oil Flow Tests of Compartment Fires with Reduced Simulation", Fire Science and Engineering, Vol. 28, No. 3, pp. 43-48 (2014). https://doi.org/10.7731/KIFSE. 2014.23.3.043.

10. S. M. Lim, Y. S. Kwon, Y. L. Cho and W. S. Chung, "A Study on the Quantitative Analysis of Portable XRF for the Components Analysis of Metal Cultural Heritage", Journal of Conservation Science, Vol. 37, No. 4, pp. 451-463 (2021). https://doi.org/10.12654/JCS.2021.37.5.04.

11. S. J. You and G. L. Chung, "A Study on the Application of Metal-Based Forensic Evidence Using the Portable X-ray Fluorescence", Journal of Police Science, Vol. 18, No. 3, pp. 193-206 (2018). http://doi.org/10.22816/polsci.2018.18. 3.008

12. S. J. Choi, J. H. Kim, S. G. Lee and D. P. Kim, "Comparison Study of the Wear Metal Analysis in Oil Sample by Portable and Bench-top XRF", Analytical Science \& Technology, Vol. 22, No. 5, pp. 422-431 (2009).

13. J. W. Lee, "Optimized Incident Ion Energy Determined by Shadow Cone and K Shell Ionization for the Thermal Vibration Correlation with Ion Scattering", New Physics : Sae Mulli, Vol. 70, No. 11, pp. 992-1002 (2020). https://doi. org/10.3938/NPSM.70.992.

14. L. Natarajan, "Relativistic Calculations on the $\mathrm{K}_{\alpha} \mathrm{X}$-ray Satellites of Platinum with Multiply Ionized L Shell", Journal of Physics B: Atomic, Molecular and Optical Physics, Vol. 52, No. 1, pp. 15002-15013 (2019). https://doi.org/ 10.1088/1361-6455/aaed67.

15. B. W. Lee, "Content Analysis of Interference and Diffraction Presented in High School Physics Textbooks", New Physics : Sae Mulli, Vol. 70, No. 12, pp. $1092-1100$ (2020). https://doi.org/10.3938/MPSM.70.1092.

16. Y. J. Cho and K. S. Yang, "Analysis of Nonlinear Destructive Interaction between Wind and Wave Loads Acting on the Offshore Wind Energy Converter Based on the Hydraulic Model Test", Korean Society of Coastal and Ocean Engineers, Vol. 27, No. 5, pp. 281-294 (2015). https://doi.org/10.9765/ KSCOE.2015.27.5.281. 